\title{
Incorporation of conjugated linoleic and alpha linolenic fatty acids into Pimedolus maculatus fillets
}

Ana Beatriz ZANQUI ${ }^{1}$, Swami Arêa MARUYAMA ${ }^{1}$, Deoclécio José BARILLI², Suellen Andressa Oenning RIBEIRO ${ }^{1}$, Sandra Terezinha Marques GOMES ${ }^{1}$, Jesuí Vergílio VISENTAINER ${ }^{1}$, Nilson Evelázio de SOUZA ${ }^{1}$, Wilson Rogério BOSCOLO ${ }^{2}$, Makoto MATSUSHITA ${ }^{1 *}$

\begin{abstract}
The objective of this study was to investigate the fatty acid composition of Pimedolus maculatus fillets of fish fed with different diets. The fish were submitted to an adaptation period (over 30 days) and fed only a control diet (diet I). After this period, the fish were divided into two groups: one group received a diet enriched with flaxseed oil (diet II), and the other received a diet enriched with conjugated linoleic acid (CLA) (diet III). Subsequent collections were undertaken after 25 and 50 days. Compared to the control samples, fish fed diet II showed an increase in concentrations of total fatty acid omega-3 (n-3) in the fillets, with an improvement ratio of $n-6 / n-3$. The incorporation of CLA into fish fed diet III was successful. Supplementing the diet of Pimedolus maculatus with CLA and flaxseed oil led to improvements in nutritional quality and fatty acid profile of the fish fillets.
\end{abstract}

Keywords: polyunsaturated fatty acids; gas chromatography; fatty acids profile.

\section{Introduction}

Fish farming has been intensively expanding over the last twenty-six years. This trend has generated concerns about the most suitable diet for each species and whether the quality of meat derived from these farmed fish accords with consumers the expectations of consumers, who increasingly demand products with the same health benefits as those originally provided by wild fish (BANDARRA et al., 2006).

In seeking to achieve these health benefits, many researchers have developed diets specially designed for the production of fish meat with a high content of polyunsaturated fatty acids (PUFA), which can lead to beneficial omega-3/omega-6 ratios, known to prevent a series of human diseases such as coronary heart disease, cardiovascular disease, rheumatoid arthritis, depression, postpartum depression, cancers, and diabetes, and have anti-inflammatory action (GULER et al., 2008; JUSTI et al., 2003; MARTINO et al., 2002; NAVARRO et al., 2012; SCHIEPERS et al., 2010; VISENTAINER et al., 2005; ŻMIJEWSKI et al., 2006; ZURAINI et al., 2006). The difference between these diets is the use of lipid sources high in omega-3 fatty acids, such as flaxseed oil (MARTINO et al., 2002).

Increased lipid content in diets is very attractive to the farming industry because lipids are a good energy source, which leads to greater protein sparing, improvements in feed conversion, and a decrease in the amount of waste produced by fish (GHANAWI et al., 2011; KENNEDY et al., 2005; MANNING et al., 2006; RAMOS et al., 2008). However, such an increase can lead to changes in body composition and slaughter quality, which lead to a negative impact regarding the overall market quality of fish due to an excessive deposition of fat in tissues such as the abdomen, liver and muscles (BANDARRA et al., 2006; KENNEDY et al., 2007; MANNING et al., 2006; RAMOS et al., 2008).

These deleterious aspects can be compensated if compounds that promote human health, such as conjugated linoleic acids (CLA), are included in the diet of fish (RAMOS et al., 2008).

The term CLA is used to denote positional, geometric, and conjugated isomers of linoleic acid (18:2n-6) that are found naturally in dairy and meat produce; the two most biologically active isomers are cis-9, trans-11 and trans-10, cis-12 (BANDARRA et al., 2006; KENNEDY et al., 2007; LEAVER et al., 2006; RAMOS et al., 2008; TAN et al., 2010).

CLA is used by humans as a nutritional supplement, and it is possible to add this component to the diets of living beings such as fish (MANNING et al., 2006). Although fish are a poor source of CLA, they show very high deposition rates of these fatty acids in their muscles, leading to the hypothesis that the consumption of these fish is an efficient means of raising human intake of CLA (FIGUEIREDO-SILVA et al., 2005; MANNING et al., 2006).

Thus, the enrichment of fish with omega-3 and CLA fatty acids can produce final products with the quality expected by human consumers and overcome the economic problems common in the fish farming industry.

Dietary CLA may change growth responses, feed efficiency, and lipid concentration in certain species of fish. It is still not very clear why dietary CLA reduces fat accumulation, but the following factors are strongly related with this effect: inhibition of lipid absorption, lipogenesis, and the promotion of lipid oxidation (FIGUEIREDO-SILVA et al., 2005).

${ }^{1}$ Department of Chemistry, State University of Maringa - UEM, Av. Colombo, 5790, CEP 87020-900, Maringá, PR, Brazil, e-mail: mmakoto@uem.br

${ }^{2}$ Department of Exact Sciences and Engineering, State University of Western Paraná - UNIOESTE, Toledo, PR, Brazil

${ }^{*}$ Corresponding author 
Mandi (Pimedolus maculatus) is a freshwater catfish with fast rate of growth, excellent alimentary conversion, easy adaptation to farming in tanks, and good quality meat. It is an abundant species with great importance for commercial fishing in the regions of the Amazon, Guianas, Venezuela, Peru, Bolivia, Paraguay and Argentina, and it is well-accepted by the consumer market (GODOY, 1987; LOLIS; ANDRIA, 1996).

There is no available information regarding the fatty acid profile of the Mandi, and its supplementation by omega-3 fatty acids and CLA can lead to fillets of a better nutritional quality. Such incorporation is important, so that Mandi consumers from the regions cited above can enjoy the health benefits of its enhanced meat. Thus, the objective of this study was to evaluate the fatty acid composition in Mandi fillets fed with flaxseed oil and CLA-enriched rations.

\section{Materials and methods}

The experiments with Mandi were performed at the Salto Caxias power plant reservoir, located in the municipality of Boa Vista da Aparecida, state of Paraná, Brazil. Each assay was composed of 1200 fish distributed randomized in 24 pound nets (50 fish per pound net) with four treatments and six repetitions.

The experimental diets used (Table 1 and 2), formulated according to the American Research Council (NRC) (NATIONAL..., 1993) recommendations, were isophosphoric, isoenergetic, and isoproteic, and flaxseed oil and conjugated linoleic acid (LUTA-CLA ${ }^{\circledast}$ 60, BASF) were incorporated into the extruded commercial ration.

The fish were submitted to an adaptation period of 30 days and fed only with a control diet (diet I). After this period, they were divided into two groups: one received a diet enriched

Table 1. Experimental composition ( $\mathrm{g}$ per $\mathrm{kg}$ ) of the experimental diets ${ }^{\mathrm{a}}$.

\begin{tabular}{cccc}
\hline Ingredients & $\begin{array}{c}\text { Diet I } \\
(\text { Control) }\end{array}$ & $\begin{array}{c}\text { Diet II } \\
\text { (LNA) }\end{array}$ & $\begin{array}{c}\text { Diet III } \\
\text { (CLA) }\end{array}$ \\
\hline Soybean oil & 40.0 & 21.5 & 23.3 \\
Flaxseed oil $^{\mathrm{b}}$ & 0.00 & 18.5 & 0.00 \\
LUTA-CLA $^{\circledR}$ 60 - BASF suplement & \\
\hline
\end{tabular}

${ }^{a}$ Extruded commercial ration $5 \mathrm{~mm}$ Supra ${ }^{\star}$ with the following warranty levels: Vit. $\mathrm{A}=10.000 \mathrm{mg}$; vit. D3 = $3.000 \mathrm{mg}$; vit. $\mathrm{E}=800 \mathrm{mg}$; vit. $\mathrm{K} 3=5 \mathrm{mg}$; vit. $\mathrm{B} 1=5 \mathrm{mg}$; vit. $\mathrm{B} 2=10 \mathrm{mg}$; vit. $\mathrm{B} 6=6 \mathrm{mg}$; vit. $\mathrm{B} 12=12 \mathrm{mcg}$; Folic acid $=1 \mathrm{mg}$; pantothenic acid $=50 \mathrm{mg}$; vit. $\mathrm{C}=250 \mathrm{mg}$; biotin $=0.5 \mathrm{mg}$; choline $=2.000 \mathrm{mg}$; niacin $=80 \mathrm{mg} ; \mathrm{Fe}=40 \mathrm{mg}$; $\mathrm{Cu}=20 \mathrm{mg} ; \mathrm{Mn}=30 \mathrm{mg} ; \mathrm{Zn}=100 \mathrm{mg} ; \mathrm{I}=5 \mathrm{mg}$ and $\mathrm{Se}=0.4 \mathrm{mg} .{ }^{\mathrm{b}} \mathrm{Commercial}$ product containing $54 \%$-linolenic acid. 'LUTA-CLA 60 BASF supplement (BASF AG, Ludwigshafen, Germany), containing 60\% CLA methyl esters as a 50:50 mixture of $9 c$, $11 t$ and $10 t, 12 c$ isomers.

Table 2. Proximate composition ( $\mathrm{g}$ per $\mathrm{kg}$ ) of the experimental diets ${ }^{\mathrm{a}}$.

\begin{tabular}{cccr}
\hline Ingredients & $\begin{array}{c}\text { Diet I } \\
(\text { Control })\end{array}$ & $\begin{array}{c}\text { Diet II } \\
(\text { LNA })\end{array}$ & \multicolumn{1}{c}{$\begin{array}{c}\text { Diet III } \\
(\text { CLA })\end{array}$} \\
\hline Moisture & $75.0 \pm 0.10$ & $73.6 \pm 0.40$ & $76.4 \pm 0.02$ \\
Crude protein & $323.0 \pm 3.80$ & $329.7 \pm 3.14$ & $319.2 \pm 3.38$ \\
Total lipids & $86.0 \pm 3.00$ & $82.5 \pm 2.30$ & $85.5 \pm 2.91$ \\
Ash & $104.7 \pm 0.10$ & $106.0 \pm 0.40$ & $105.6 \pm 0.20$ \\
a-linolenic acid & 0.00 & 10.0 & 0.00 \\
Conjugated linoleic acid & 0.00 & 0.00 & 10.0 \\
\hline
\end{tabular}

\footnotetext{
a Values determined at a laboratory (CromAlimentos-UEM, Maringá, Paraná state, Brazil).
}

with flaxseed oil and codified as LNA (diet II), while the other was fed a diet enriched with CLA and codified with the same abbreviation (diet III). The fish were fed ad libitum three times per day, corresponding to $2 \%$ of the corporal weight, adjusted weekly.

\subsection{Sampling}

Immediately after the adaptation period and before the administration of the enhanced diets, three fish from each pound net were collected to determine the initial composition of the fillets. Subsequent collections were undertaken after 25 and 50 days. After every collection, the fish were killed using a xylocaine super dosage (10 g/L), weighed, gutted, and filleted. The fillets were crushed in a multiprocessor, homogenized, and packed in polyethylene bags. The samples were stored in a freezer $\left(-24^{\circ} \mathrm{C}\right)$ under a nitrogen atmosphere until analyses.

\subsection{Physicochemical analyses}

Moisture, crude protein, and ash content were determined using the Association of Official Analytical Chemists (AOAC) and Kjedahl methods (CUNNIFF, 1998).

\subsection{Total lipids, fatty acids, and synthesis of fatty acid methyl esters}

The samples were thawed at room temperature (approximately $25^{\circ} \mathrm{C}$ ) and then submitted to a lipid extraction process with a chloroform, methanol, and water mixture in the proportion of $2: 2: 1.8(\mathrm{v} / \mathrm{v} / \mathrm{v})$, respectively, according to the method proposed by Bligh and Dyer (1959). The total lipid content was determined by gravimetric techniques. The synthesis of the fatty acid methyl esters was achieved using the method proposed by Hartman and Lago (1973).

\subsection{Analysis of fatty acid methyl esters}

The fatty acid methyl esters (FAME) were separated by gas chromatography using a Shimadzu GC-14-A (Japan), equipped with a flame ionization detector and a capillary column of fused silica (CP-7420 Select FAME, Varian, USA; $100 \mathrm{~m}$ length, $0.25 \mathrm{~mm}$ internal diameter and $0.25 \mu \mathrm{m}$ cyanoproyl film). Initially, the column temperature was maintained at $165^{\circ} \mathrm{C}$ for 18 minutes. It was then raised to $180^{\circ} \mathrm{C}$, at a rate of $30^{\circ} \mathrm{C} / \mathrm{min}$, and kept at this temperature for two minutes. After this period, it was once again raised to $240{ }^{\circ} \mathrm{C}$ at a rate of $15^{\circ} \mathrm{C} / \mathrm{min}$ and maintained for 20 minutes. Both injector and column temperatures were $260^{\circ} \mathrm{C}$. The flow rates of the carrier $\left(\mathrm{H}_{2}\right)$, auxiliary $\left(\mathrm{N}_{2}\right)$, and detector flame $\left(\mathrm{H}_{2}\right.$ and synthetic air) gases (provided by Praxair Inc.) were $1.2 \mathrm{~mL} / \mathrm{min}, 30 \mathrm{~mL} / \mathrm{min}$, $30 \mathrm{~mL} / \mathrm{min}$, and $300 \mathrm{~mL} / \mathrm{min}$, respectively. Approximately two microliters of sample were injected, at a split ratio of $1 / 50$.

The detection and quantification limits were estimated according to the Analytical Methods Committee (ANALYTICAL..., 1987). recommendations: the signal/noise ratios were determined to be equal to three and 10 , respectively, 
achieved with successive dilutions of a methyl araquidate standard solution.

\subsection{Chromatographic analysis of fatty acids}

The fatty acids were identified through comparing the FAME peak retention times with the standard compound peaks (provided by Sigma Chemical Co.). All the peak areas were calculated using the software Clarity Lite version 2.4.1.91.

The absolute quantification of the fatty acids in $\mathrm{mg} / \mathrm{g}$ of total lipids was achieved in relation to the internal standard, methyl tricosanoate. The calculations were performed according to Joseph and Ackman (1992), using the following Equation 1:

$$
F A(m g / g)=\frac{A_{x} \times W_{I S} \times C F_{x}}{A_{I S} \times W_{x} \times C F_{A E}}
$$

where $A_{x}$ is the peak area (of a specific fatty acid), $A_{I S}$ is the internal standard peak area, $\mathrm{W}_{\mathrm{IS}}$ is the IS weight $(\mathrm{mg})$ added to the sample, $\mathrm{W}_{\mathrm{x}}$ is the sample weight $(\mathrm{mg}), \mathrm{CF}_{\mathrm{x}}$ is the theoretical correction factor, and $\mathrm{CF}_{\mathrm{AE}}$ is the conversion factor necessary to express the results in terms of fatty acids instead of methyl esters.

\subsection{Statistical analysis}

The results were submitted to variance analysis (ANOVA) at significance level of $5 \%$ using the statistical software SAS v 9.1 (SAS Institute; Cary, NC), and the means were compared using the Tukey's test.

\section{Results and discussion}

Tables 3 and 4 shows the fatty acid profile (expressed in percentage of total fatty acids) of the experimental diets. With regards to fish health, the essential fatty acids (EFA) for fish are PUFAs from both the n-3 and n- 6 series with carbon chain lengths of 18,20 , and 22 . These fatty acids must be provided as dietary supplements to meet fish requirements because they cannot be synthesized by the fish although some species can convert 18-carbon PUFAs to fatty acids of the same series with longer carbonic chains and a higher degree of unsaturation (BLANCHARD; MAKOMBU; KESTEMONT, 2008; RODRIGUÉZ; PÉREZ; HENDERSON, 2002; SMITH et al., 2004; TURCHINI; FRANCIS; DE SILVA, 2006; WU; CHEN, 2012). The roles of EFA in fish are: maintenance of membranes, eicosanoid metabolism, and reproductive performance (NG; WANG, 2011; SARGENT et al., 1999; SMITH et al., 2004). The results shown in Tables 3 and 4 indicate that the experimental diets have all of the fatty acids that are needed for proper fish growth.

Table 5 shows the results of the physicochemical analyses of the Mandi fillets submitted to the different treatments, at the beginning of the procedure and after 25 and 50 days. A comparison of all data obtained after 50 days showed that the treatment with flaxseed oil resulted in fillets with a total lipid content slightly greater than that obtained using the regular diet (control 50), and no significant difference was observed between
Table 3. Fatty acid profile (\% of total fatty acids) of the experimental $\operatorname{diets}^{\mathrm{a}}$

\begin{tabular}{|c|c|c|c|}
\hline Fatty acid & Diet I (Control) & Diet II (LNA) & Diet III (CLA) \\
\hline 14:0 & $0.85^{a, b} \pm 0.02$ & $0.90^{\mathrm{a}} \pm 0.07$ & $0.76^{b} \pm 0.07$ \\
\hline $14: 1 n-7$ & $0.09^{\mathrm{a}} \pm 0.01$ & $0.10^{\mathrm{a}} \pm 0.01$ & $0.10^{\mathrm{a}} \pm 0.01$ \\
\hline $15: 0$ & $0.20^{\mathrm{a}, \mathrm{b}} \pm 0.01$ & $0.21^{\mathrm{a}} \pm 0.01$ & $0.19^{b} \pm 0.01$ \\
\hline $15: 1 n-9$ & $0.08^{\mathrm{a}} \pm 0.01$ & $0.08^{\mathrm{a}} \pm 0.01$ & $0.08^{\mathrm{a}} \pm 0.01$ \\
\hline $16: 0$ & $18.19^{\mathrm{a}} \pm 1.36$ & $15.92^{\mathrm{a}} \pm 1.07$ & $17.05^{\mathrm{a}} \pm 0.67$ \\
\hline $16: 1 n-9$ & $0.16^{\mathrm{b}} \pm 0.02$ & $0.20^{\mathrm{a}} \pm 0.01$ & $0.17^{\mathrm{a}, \mathrm{b}} \pm 0.01$ \\
\hline $16: 1 n-7$ & $1.19^{\mathrm{b}} \pm 0.06$ & $1.29^{\mathrm{a}} \pm 0.09$ & $1.17^{\mathrm{b}} \pm 0.05$ \\
\hline $16: 1 n-5$ & $0.18^{\mathrm{a}} \pm 0.01$ & $0.15^{\mathrm{b}} \pm 0.01$ & $0.19^{\mathrm{a}} \pm 0.01$ \\
\hline $17: 0$ & $0.42^{\mathrm{a}, \mathrm{b}} \pm 0.03$ & $0.37^{\mathrm{b}} \pm 0.01$ & $0.45^{\mathrm{a}} \pm 0.01$ \\
\hline $17: 1 n-9$ & $0.14^{\mathrm{a}} \pm 0.01$ & $0.13^{\mathrm{a}} \pm 0.01$ & $0.14^{\mathrm{a}} \pm 0.01$ \\
\hline $18: 0$ & $7.43^{\mathrm{a}, \mathrm{b}} \pm 0.62$ & $6.72^{b} \pm 0.51$ & $8.43^{\mathrm{a}} \pm 0.14$ \\
\hline $18: 1(11 t)$ & $0.60^{a, b} \pm 0.13$ & $0.48^{\mathrm{b}} \pm 0.02$ & $0.57^{\mathrm{a}, \mathrm{b}} \pm 0.02$ \\
\hline $18: 1 n-9$ & $27.60^{\mathrm{a}, \mathrm{b}} \pm 2.10$ & $25.26^{\mathrm{b}} \pm 0.82$ & $29.32^{\mathrm{a}} \pm 0.42$ \\
\hline $18: 1 n-7$ & $1.00^{\mathrm{a}, \mathrm{b}} \pm 0.06$ & $0.93^{b} \pm 0.03$ & $1.03^{\mathrm{a}, \mathrm{b}} \pm 0.04$ \\
\hline $18: 2 n-6$ & $37.08^{\mathrm{a}} \pm 4.39$ & $29.53^{b, c} \pm 0.47$ & $25.77^{c} \pm 0.23$ \\
\hline $18: 3 n-6$ & $0.10^{\mathrm{a}} \pm 0.02$ & $0.08^{\mathrm{a}} \pm 0.01$ & $0.04^{\mathrm{b}} \pm 0.01$ \\
\hline $18: 3 n-3$ & $2.95^{c} \pm 0.25$ & $15.68^{a} \pm 1.03$ & $1.68^{c} \pm 0.02$ \\
\hline $20: 1 n-9$ & $0.48^{\mathrm{a}} \pm 0.06$ & $0.19^{b} \pm 0.01$ & $0.22^{\mathrm{b}} \pm 0.02$ \\
\hline $18: 2(9 c, 11 t)$ & $\mathrm{nd}^{\mathrm{b}}$ & nd & $6.03^{\mathrm{a}} \pm 0.13$ \\
\hline $18: 2(10 t, 12 c)$ & nd & nd & $5.87^{\mathrm{a}} \pm 0.12$ \\
\hline $20: 2 n-6$ & $0.21^{\mathrm{a}} \pm 0.01$ & $0.14^{\mathrm{b}} \pm 0.01$ & $0.22^{\mathrm{a}} \pm 0.01$ \\
\hline $20: 3 n-6$ & $0.47^{\mathrm{a}} \pm 0.04$ & $0.05^{\mathrm{b}} \pm 0.01$ & $0.04^{\mathrm{b}} \pm 0.01$ \\
\hline $22: 0$ & $0.41 \pm 0.03$ & nd & nd \\
\hline $22: 1 n-9$ & $0.22^{\mathrm{a}} \pm 0.02$ & $0.05^{b} \pm 0.01$ & $0.04^{b} \pm 0.01$ \\
\hline $20: 3 n-3$ & $0.21^{\mathrm{a}} \pm 0.05$ & $0.21^{\mathrm{a}} \pm 0.01$ & $0.14^{\mathrm{b}} \pm 0.01$ \\
\hline $20: 4 n-6$ & $0.17^{\mathrm{a}} \pm 0.02$ & $0.12^{c} \pm 0.01$ & $0.16^{\mathrm{a}, \mathrm{b}} \pm 0.01$ \\
\hline $20: 5 n-3$ & nd & $0.08^{\mathrm{a}} \pm 0.01$ & $0.04^{\mathrm{b}} \pm 0.01$ \\
\hline
\end{tabular}

a.b, Averages followed by different letters in the same line are significantly different $(\mathrm{p}<0.05)$ according to Tukey's test. n.d. $=$ not detected $($ detection limit $=0.015 \%)$.

Table 4. Fatty acid profile (\% of total fatty acids) of the experimental diets-part $2^{\mathrm{a}}$.

\begin{tabular}{cccc}
\hline Fatty acid & Diet I (Control) & Diet II (LNA) & Diet III (CLA) \\
\hline SFA $^{\mathrm{b}}$ & $27.50^{\mathrm{a}} \pm 0.74$ & $24.12^{\mathrm{b}} \pm 1.43$ & $26.88^{\mathrm{a}} \pm 0.64$ \\
MUFA $^{\mathrm{c}}$ & $31.74^{\mathrm{a}, \mathrm{b}} \pm 2.12$ & $28.87^{\mathrm{b}} \pm 0.68$ & $33.04^{\mathrm{a}} \pm 0.42$ \\
PUFA $^{\mathrm{d}}$ & $41.20^{\mathrm{a}, \mathrm{b}} \pm 4.18$ & $45.89^{\mathrm{a}} \pm 1.39$ & $39.98^{\mathrm{b}} \pm 0.46$ \\
$\mathrm{n}-6^{\mathrm{e}}$ & $38.03^{\mathrm{a}} \pm 4.37$ & $29.93^{\mathrm{b}} \pm 0.47$ & $38.13^{\mathrm{a}} \pm 0.45$ \\
n-3 & $3.63^{\mathrm{c}} \pm 0.32$ & $16.02^{\mathrm{a}} \pm 1.04$ & $1.90^{\mathrm{d}} \pm 0.02$ \\
PUFA/SFA & $1.50^{\mathrm{b}} \pm 0.12$ & $1.91^{\mathrm{a}} \pm 0.13$ & $1.49^{\mathrm{b}} \pm 0.05$ \\
n-6/n-3 & $10.56^{\mathrm{b}} \pm 1.92$ & $1.87^{\mathrm{d}} \pm 0.10$ & $20.11^{\mathrm{a}} \pm 0.08$
\end{tabular}

${ }^{a}$ Averages followed by different letters in the same line are significantly different $(p<0.05)$ according to Tukey's test. ${ }^{b} S F A=$ sum of saturated fatty acids. ${ }^{c}$ MUFA $=$ sum of monounsaturated fatty acids. ${ }^{d}$ PUFA $=$ sum of polyunsaturated fatty acids. ${ }^{e} n-6=$ sum of omega 6 fatty acids. ${ }^{\mathrm{f}} \mathrm{n}-3=$ sum of omega 3 fatty acids.

the diets with CLA and without any supplementation. Since these percentage increases are no higher than approximately $12.95 \%$, it can be assumed that the fillet quality of the enriched final products probably did not undergo negative changes.

Table 6 shows the results of the absolute quantification of fatty acids of the Mandi fillets submitted to the treatment 
Table 5. Composition of the fillets of the Pimedolus maculatus in $\left(\mathrm{g} \mathrm{kg}^{-1}\right)^{\mathrm{a}}$.

\begin{tabular}{lcccc}
\hline \multicolumn{1}{c}{ Parameters } & Moisture & Ash & Crude Protein & Total Lipids \\
\hline Initial time & $76.323 \mathrm{a} \pm 1.707$ & $1.006^{\mathrm{a}} \pm 0.014$ & $19.908^{\mathrm{ab}} \pm 0.667$ & $4.665^{\mathrm{a}} \pm 0.275$ \\
Diet I-25 Days & $74.613^{\mathrm{a}} \pm 1.984$ & $1.283^{\mathrm{b}} \pm 0.004$ & $19.819^{\mathrm{ab}} \pm 0.220$ & $6.441^{\mathrm{b}} \pm 0.104$ \\
Diet I-50 Days & $75.000^{\mathrm{a}} \pm 0.290$ & $0.978^{\mathrm{a}} \pm 0.043$ & $18.342^{\mathrm{c}} \pm 0.460$ & $5.709^{\mathrm{c}} \pm 0.183$ \\
Diet II-25 Days & $75.554^{\mathrm{a}} \pm 1.067$ & $0.954^{\mathrm{a}} \pm 0.046$ & $18.167^{\mathrm{c}} \pm 0.230$ & $4.465^{\mathrm{a}} \pm 0.015$ \\
Diet II-50 Days & $75.304^{\mathrm{a}} \pm 0.206$ & $1.179^{\mathrm{bc}} \pm 0.003$ & $18.927^{\mathrm{bc}} \pm 0.387$ & $6.453^{\mathrm{b}} \pm 0.079$ \\
Diet III-25 Days & $72.946^{\mathrm{a}} \pm 0.316$ & $1.222^{\mathrm{b}} \pm 0.049$ & $20.242^{\mathrm{a}} \pm 1.449$ & $4.824^{\mathrm{a}} \pm 0.147$ \\
Diet III-50 Days & $75.997^{\mathrm{a}} \pm 0.426$ & $1.068^{\mathrm{ac}} \pm 0.036$ & $18.971^{\mathrm{abc}} \pm 0.730$ & $6.013^{\mathrm{bc}} \pm 0.166$ \\
\hline
\end{tabular}

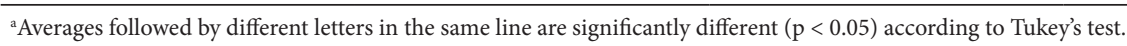

Table 6. Quantification (in $\mathrm{mg} \mathrm{g}^{-1}$ of total lipids) of fatty acids in Pimedolus maculatus fillets fed with control and flaxseed oil enhanced rations ${ }^{\mathrm{a}}$.

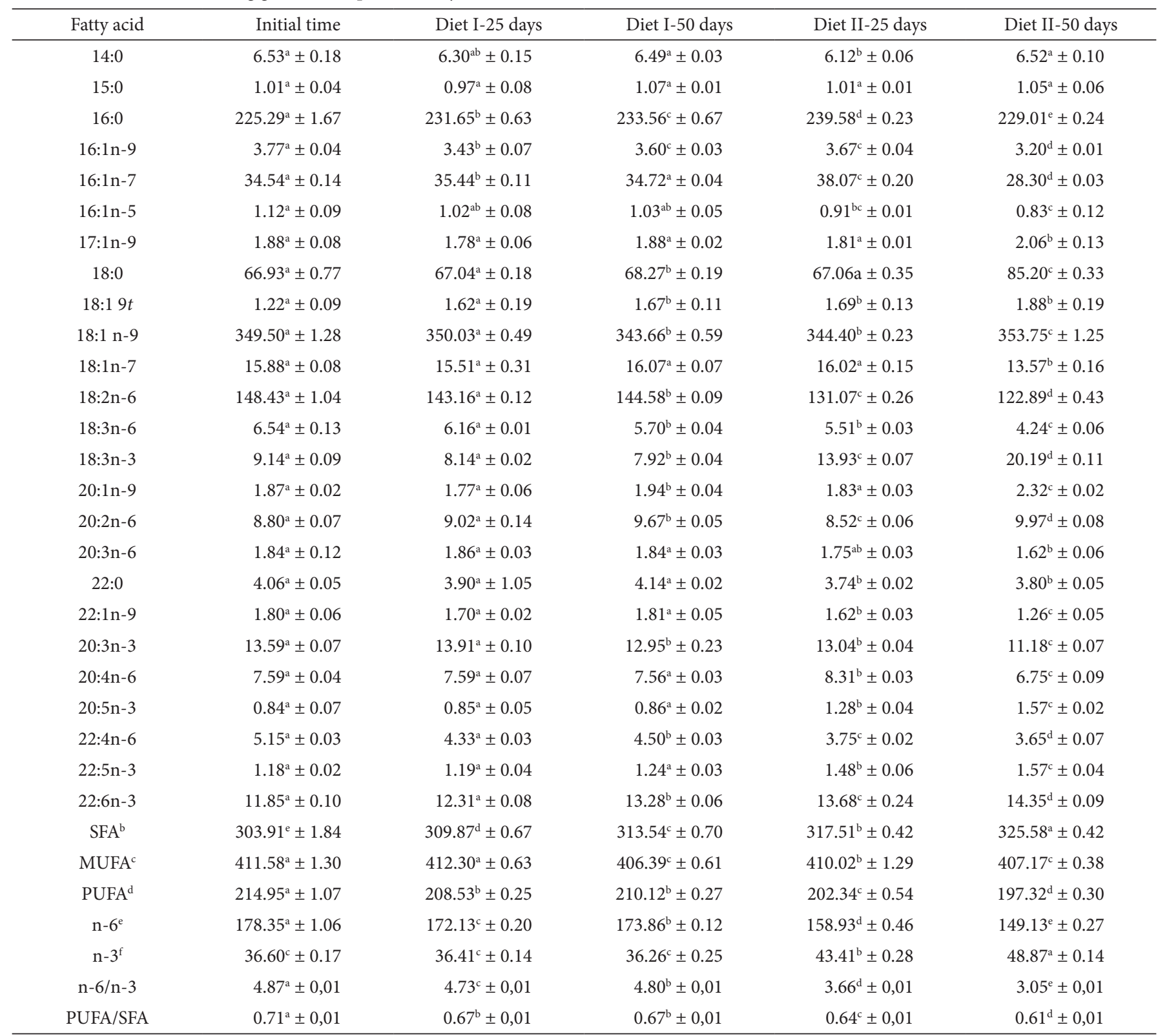

${ }^{a}$ Averages followed by different letters in the same line are significantly different $(\mathrm{p}<0.05)$ according to Tukey's test. SFA, total saturated fatty acid; MUFA, total monounsaturated fatty acid; PUFA, total polyunsaturated fatty acid; $\mathrm{n}-6$, total $\mathrm{n}-6$ fatty acid; $\mathrm{n}-3$, total $\mathrm{n}-3$ fatty acid; SE, standard error; nd, not detected (detection limit $=0.015 \mathrm{mg} \mathrm{g}^{-1}$ ). ${ }^{\text {bSFA }}=$ sum of saturated fatty acids. ${ }^{c}$ MUFA $=$ sum of monounsaturated fatty acids. ${ }^{\text {P }} \mathrm{PUFA}=$ sum of polyunsaturated fatty acids. ${ }^{\mathrm{e}} \mathrm{n}-6=$ sum of omega 6 fatty acids. ${ }^{\mathrm{f}} \mathrm{n}-3=$ sum of omega 3 fatty acids. 
using a $2.0 \%$ flaxseed oil-enhanced ration, at the beginning of the experiment and after 25 and 50 days. Comparing the results shown in Table 6, it can be observed that the fatty acid composition of the samples obtained after 50 days of feeding with the flaxseed oil-enhanced ration is significantly different from the data obtained after 50 days of feeding with the regular ration (control 50). The former showed an amount of a-linolenic acid (18:3n-3), which was $154.92 \%$ greater than the latter. The omega-3 fatty acids, Eicosapentaenoic Acid (EPA), Docosapentaenoic Acid (DPA), and Docosahexaenoic Acid (DHA), also showed an increase in content by $82.55 \%, 26.61 \%$, and $8.05 \%$, respectively. The only exception was $20: 3 n-3$, with a $13.66 \%$ decrease.

It is important to mention that the amount of $18: 3 n-3$ $(20.19 \pm 0.11)$ is greater than that reported for the muscle tissue of fish such as Lateolabrax japonicus (Japanese Sea Bass) reared in seawater $(1.08 \pm 0.08)$ and freshwater $(0.78 \pm 0.05)$ (XU et al., 2010).

A decrease in the arachidonic acid (20:4n-6) content in all of the samples was also observed; this occurred because it is a precursor for a series of compounds such as prostaglandin and thromboxan, which are highly important for the proper attachment of a blood clot to the endothelial tissue during wound healing (GULER et al., 2008; RAHMAN et al., 1995) and for eicosanoids that are employed in the regulation of ion and water fluxes in the gills and kidneys of fish (BENDIKSEN; ARNESEN; JOBLING, 2003).

The EPA content of the fish fed with the enriched ration for 50 days $(1.57 \pm 0.02)$ was greater than that obtained for Nile Tilapia (Oreochromis niloticus) fed with a similar ration, using $2.50 \%$ instead of $2.0 \%$ flaxseed oil for 150 days $(0.8 \pm 0.1)$ (VISENTAINER et al., 2005). Thus, the incorporation of this fatty acid into Mandi fillets is more efficient than into Nile Tilapia samples due to the advantage of being able to use a lower amount of flaxseed oil in the formulation of the diet within a shorter period of time (100 days less).

EPA and DHA have a very important role in the prevention of coronary heart disease in humans (GULER et al., 2008; HUYNH; KITTS, 2009; INHAMUNS; FRANCO; BATISTA, 2009; JI; LI; LIU, 2011; MEMON et al., 2011; RAHMAN et al., 1995). DHA is also required for adequate brain and eye development in infants. A reduction in the levels of beta amyloid plaque, the substance associated with Alzheimer's disease, was shown to occur in aged laboratory mice fed diets enriched with DHA (MANNING et al., 2006).

The values for the sums of the omega-3 (n-3) and omega- 6 (n-6) fatty acids supported the results of the 50 flaxseed treatment samples, which showed lower omega- 6 FA and higher omega-3 FA overall content than that of the control 50 treatment samples and, thus, a lower $n-6 / n-3$ ratio. Simopoulos (2011) found that the optimal omega-6/omega-3 fatty acid ratio for human intake varies from 1 to 2 . This conclusion is based on other medical research, which evaluated the relationship of the ingestion essential fatty acids and the healing rate of patients with chronic diseases. Based on this consideration, it was observed that the fish fed an enriched ration for 50 days had the ideal ratio closer to that stipulated by Simopoulos (2011) than that found in the fish fed the control ration. Thus, it can be concluded that feed supplementation with flaxseed oil contributed to the formulation of a product with a more balanced fatty acid composition.

Table 7 shows the results, at the beginning and after 25 and 50 days, of the absolute quantification of fatty acids in Mandi fillets derived from fish submitted to treatment with a $1.8 \%$ CLA enhanced ration. Although the amounts of LNA and DHA in the samples obtained after 50 days of feeding with the CLA enhanced ration were lower in relation to the same fatty acid contents obtained after 50 days of feeding with the regular ration, a decrease in total content of omega- 6 fatty acids was observed. These simultaneous decreases contributed to the development of a product with an omega-6/omega-3 ratio closer to the ideal values stipulated by Simopoulos (2011).

The absolute quantification data showed that CLAs were incorporated into the fish meat successfully. These special fatty acids were first isolated from cooked ground beef, when it was determined that they perform many interesting functions in living beings, such as chemical inhibition of induced cancer in rodents and atherosclerosis in rabbits (TAN et al., 2010; TWIBELL; WILSON, 2003), as well as growth response and tissue composition changes in terrestrial animals (TWIBELL; WILSON, 2003). Increasing evidence also points to dietary CLA effect on the attenuation of obesity in several animal models through the simultaneous promotion of a decrease in body fat and increase in lean body mass (TAN et al., 2010). Thus, with the successful incorporation of CLA into the Mandi fillets, it can be concluded that human beings can enjoy the beneficial effects of CLA through consumption of this enriched fish meat.

High amounts of oleic and linoleic acid were detected in all of the fish samples used in the present study. Both acids typically occur in freshwater fish (HUYNH; KITTS, 2009; MARTINO et al., 2002; SAITO; OKABE, 2012). EPA and DHA were also detected in all of the samples. The literature reports that all fish incorporate EPA and DHA, but the amount is not equal among species and, even within a certain species, other variables such as type of diet and location contribute to this variation. It is also important to note that each individual fish species has a particular degree of modification of its dietary input, and this change occurs through two pathways: catabolism and conversion, with the inclusion of desaturation and elongation (GULER et al., 2008; INHAMUNS; FRANCO; BATISTA, 2009; TAN et al., 2010; TURCHINI et al., 2007).

To indicate if a certain food is healthy, the English Health Department (HER..., 1994) recommends that the value of the PUFA/SFA ratio must be above 0.45 . The PUFA/SFA ratios of all of the fish fillets examined in the present study were within these recommended values. 

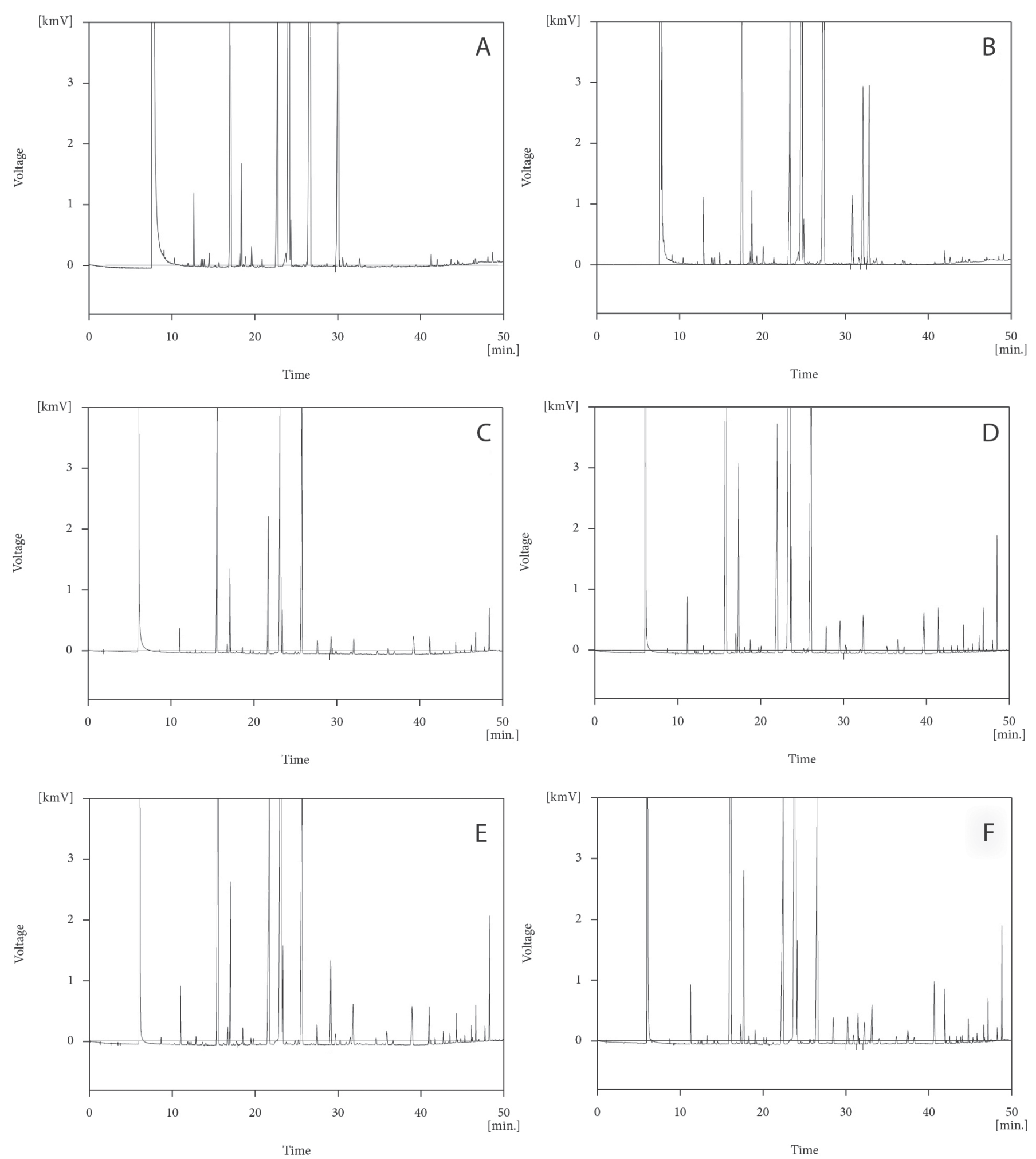

Figure 1. Typical chromatograms for: (A) Flaxseed oil enhanced ration; (B) CLA enhanced ration; (C) Initial time-50 days; (D) Fish fed diet I- 50 days; (E) Fish fed diet II- 50 days; (F) Fish fed diet III- 50 days. 
Incorporation of conjugated linoleic acids and $\alpha$-linolenic acid into Pimedolus maculatus fillets

Table 7. Absolute quantification (in $\mathrm{mg} \mathrm{g}^{-1}$ of total lipids) of fatty acids in Pimedolus maculatus fillets fed control and CLA enhanced rations ${ }^{\mathrm{a}}$.

\begin{tabular}{|c|c|c|c|c|c|}
\hline Fatty acid & Initial time & Diet I-25 days & Diet I-50 days & Diet III-25 days & Diet III-50 days \\
\hline $14: 0$ & $6.53^{\mathrm{a}} \pm 0.18$ & $6.30^{\mathrm{ab}} \pm 0.15$ & $6.49^{\mathrm{a}} \pm 0.03$ & $6.58^{a} \pm 0.10$ & $6.72^{\mathrm{a}} \pm 0.07$ \\
\hline 15:0 & $1.01^{\mathrm{a}} \pm 0.04$ & $0.97^{\mathrm{a}} \pm 0.08$ & $1.07^{\mathrm{a}} \pm 0.01$ & $1.08^{\mathrm{a}} \pm 0.03$ & $1.13^{\mathrm{a}} \pm 0.04$ \\
\hline $16: 0$ & $225.29^{\mathrm{a}} \pm 1.67$ & $231.65^{b} \pm 0.63$ & $233.56^{c} \pm 0.67$ & $235.27^{\mathrm{a}} \pm 1.81$ & $232.93^{a} \pm 0.64$ \\
\hline $16: \ln -9$ & $3.77^{\mathrm{a}} \pm 0.04$ & $3.43^{b} \pm 0.07$ & $3.60^{c} \pm 0.03$ & $3.92^{a} \pm 0.03$ & $3.63^{a} \pm 0.04$ \\
\hline $16: 1 n-7$ & $34.54^{\mathrm{a}} \pm 0.14$ & $35.44^{\mathrm{b}} \pm 0.11$ & $34.72^{\mathrm{a}} \pm 0.04$ & $35.94^{a} \pm 0.27$ & $32.03^{a} \pm 0.17$ \\
\hline $16: \ln -5$ & $1.12^{\mathrm{a}} \pm 0.09$ & $1.02^{\mathrm{ab}} \pm 0.08$ & $1.03^{\mathrm{ab}} \pm 0.05$ & $0.93^{\mathrm{a}} \pm 0.02$ & $1.03^{\mathrm{a}} \pm 0.05$ \\
\hline $17: 1 n-9$ & $1.88^{\mathrm{a}} \pm 0.08$ & $1.78^{\mathrm{a}} \pm 0.06$ & $1.88^{\mathrm{a}} \pm 0.02$ & $1.95^{\mathrm{a}} \pm 0.09$ & $2.01^{\mathrm{a}} \pm 0.01$ \\
\hline $18: 0$ & $66.93^{a} \pm 0.77$ & $67.04^{a} \pm 0.18$ & $68.27^{b} \pm 0.19$ & $69.15^{\mathrm{a}} \pm 0.51$ & $79.51^{\mathrm{a}} \pm 0.22$ \\
\hline $18: 19 t$ & $1.22^{\mathrm{a}} \pm 0.09$ & $1.62^{\mathrm{a}} \pm 0.19$ & $1.67^{\mathrm{b}} \pm 0.11$ & $2.66^{\mathrm{a}} \pm 0.07$ & $3.04^{\mathrm{a}} \pm 0.44$ \\
\hline $18: 1 \mathrm{n}-9$ & $349.50^{\mathrm{a}} \pm 1.28$ & $350.03^{a} \pm 0.49$ & $343.66^{\mathrm{b}} \pm 0.59$ & $336.01^{\mathrm{a}} \pm 0.25$ & $340.74^{\mathrm{a}} \pm 0.42$ \\
\hline $18: 1 \mathrm{n}-7$ & $15.88^{\mathrm{a}} \pm 0.08$ & $15.51^{\mathrm{a}} \pm 0.31$ & $16.07^{a} \pm 0.07$ & $15.82^{\mathrm{a}} \pm 0.07$ & $15.12^{\mathrm{a}} \pm 0.05$ \\
\hline $18: 2 n-6$ & $148.43^{\mathrm{a}} \pm 1.04$ & $143.16^{\mathrm{a}} \pm 0.12$ & $144.58^{\mathrm{b}} \pm 0.09$ & $138.88^{\mathrm{a}} \pm 0.52$ & $127.67^{a} \pm 0.11$ \\
\hline $18: 3 n-6$ & $6.54^{\mathrm{a}} \pm 0.13$ & $6.16^{a} \pm 0.01$ & $5.70^{\mathrm{b}} \pm 0.04$ & $6.75^{a} \pm 0.05$ & $5.63^{a} \pm 0.05$ \\
\hline $18: 3 n-3$ & $9.14^{\mathrm{a}} \pm 0.09$ & $8.14^{a} \pm 0.02$ & $7.92^{\mathrm{b}} \pm 0.04$ & $7.54^{a} \pm 0.06$ & $6.51^{\mathrm{a}} \pm 0.05$ \\
\hline $20: 1 n-9$ & $1.87^{\mathrm{a}} \pm 0.02$ & $1.77^{\mathrm{a}} \pm 0.06$ & $1.94^{\mathrm{b}} \pm 0.04$ & $1.82^{\mathrm{a}} \pm 0.01$ & $2.07^{\mathrm{a}} \pm 0.03$ \\
\hline $18: 2(\mathrm{c}-9, \mathrm{t}-11)$ & $\mathrm{nd}^{\mathrm{g}}$ & nd & nd & $7.24^{\mathrm{a}} \pm 0.07$ & $7.40^{\mathrm{a}} \pm 0.08$ \\
\hline $18: 2(\mathrm{t}-10, \mathrm{c}-12)$ & nd & nd & nd & $5.18^{a} \pm 0.13$ & $5.25^{\mathrm{a}} \pm 0.06$ \\
\hline $20: 2 n-6$ & $8.80^{\mathrm{a}} \pm 0.07$ & $9.02 \mathrm{a} \pm 0.14$ & $9.67^{b} \pm 0.05$ & $8.25^{a} \pm 0.33$ & $10.18^{\mathrm{a}} \pm 0.23$ \\
\hline $20: 3 n-6$ & $1.84^{\mathrm{a}} \pm 0.12$ & $1.86^{\mathrm{a}} \pm 0.03$ & $1.84^{\mathrm{a}} \pm 0.03$ & $1.73^{\mathrm{a}} \pm 0.05$ & $1.81^{\mathrm{a}} \pm 0.09$ \\
\hline $22: 0$ & $4.06^{\mathrm{a}} \pm 0.05$ & $3.90^{\mathrm{a}} \pm 1.05$ & $4.14^{\mathrm{a}} \pm 0.02$ & $3.44^{\mathrm{a}} \pm 0.12$ & $3.76^{a} \pm 0.11$ \\
\hline $22: 1 n-9$ & $1.80^{\mathrm{a}} \pm 0.06$ & $1.70^{\mathrm{a}} \pm 0.02$ & $1.81^{\mathrm{a}} \pm 0.05$ & $2.03^{a} \pm 0.04$ & $1.65^{a} \pm 0.05$ \\
\hline $20: 3 n-3$ & $13.59^{\mathrm{a}} \pm 0.07$ & $13.91^{a} \pm 0.10$ & $12.95^{\mathrm{b}} \pm 0.23$ & $13.00^{\mathrm{a}} \pm 0.30$ & $13.00^{\mathrm{a}} \pm 0.22$ \\
\hline $20: 4 n-6$ & $7.59^{a} \pm 0.04$ & $7.59^{\mathrm{a}} \pm 0.07$ & $7.56^{\mathrm{a}} \pm 0.03$ & $7.22^{a} \pm 0.27$ & $7.41^{a} \pm 0.07$ \\
\hline $20: 5 n-3$ & $0.84^{a} \pm 0.07$ & $0.85^{\mathrm{a}} \pm 0.05$ & $0.86^{\mathrm{a}} \pm 0.02$ & $0.86^{a} \pm 0.05$ & $0.82^{\mathrm{a}} \pm 0.03$ \\
\hline $22: 4 n-6$ & $5.15^{a} \pm 0.03$ & $4.33^{a} \pm 0.03$ & $4.50^{\mathrm{b}} \pm 0.03$ & $4.58^{\mathrm{a}} \pm 0.19$ & $4.51^{\mathrm{a}} \pm 0.04$ \\
\hline $22: 5 n-3$ & $1.18^{a} \pm 0.02$ & $1.19^{\mathrm{a}} \pm 0.04$ & $1.24^{\mathrm{a}} \pm 0.03$ & $1.20^{\mathrm{a}} \pm 0.03$ & $1.36^{\mathrm{a}} \pm 0.01$ \\
\hline $22: 6 n-3$ & $11.85^{\mathrm{a}} \pm 0.10$ & $12.31^{\mathrm{a}} \pm 0.08$ & $13.28^{\mathrm{b}} \pm 0.06$ & $11.69^{\mathrm{a}} \pm 0.65$ & $13.12^{\mathrm{a}} \pm 0.13$ \\
\hline $\mathrm{SFA}^{\mathrm{b}}$ & $303.91^{\mathrm{d}} \pm 1.84$ & $309.87^{c} \pm 0.67$ & $313.54^{\mathrm{b}} \pm 0.70$ & $315.52^{b} \pm 1.89$ & $324.06^{a} \pm 0.69$ \\
\hline MUFA $^{c}$ & $411.58^{\mathrm{a}} \pm 1.30$ & $412.30^{\mathrm{a}} \pm 0.63$ & $406.39^{b} \pm 0.61$ & $401.06^{\mathrm{d}} \pm 0.40$ & $401.30^{\mathrm{d}} \pm 0.64$ \\
\hline PUFA $^{\mathrm{d}}$ & $214.95^{\mathrm{a}} \pm 1.07$ & $208.53^{b} \pm 0.25$ & $210.12^{\mathrm{b}} \pm 0.27$ & $214.11^{\mathrm{a}} \pm 1.01$ & $204.68^{c} \pm 0.40$ \\
\hline$n-6^{e}$ & $178.35^{\mathrm{a}} \pm 1.06$ & $172.13^{c} \pm 0.20$ & $173.86^{\mathrm{b}} \pm 0.12$ & $167.41^{\mathrm{d}} \pm 0.70$ & $157.22^{\mathrm{e}} \pm 0.28$ \\
\hline$n-3^{\mathrm{f}}$ & $36.60^{\mathrm{a}} \pm 0.17$ & $36.41^{\mathrm{a}} \pm 0.14$ & $36.26^{\mathrm{a}} \pm 0.25$ & $34.28^{\mathrm{b}} \pm 0.72$ & $34.80^{\mathrm{b}} \pm 0.26$ \\
\hline$n-6 / n-3$ & $4.87^{a} \pm 0,01$ & $4.73^{\mathrm{b}} \pm 0,01$ & $4.80^{\mathrm{ab}} \pm 0,01$ & $4.88^{\mathrm{a}} \pm 0,02$ & $4.52^{c} \pm 0,01$ \\
\hline PUFA/SFA & $0.71^{\mathrm{a}} \pm 0,01$ & $0.67^{\mathrm{b}} \pm 0,01$ & $0.67^{\mathrm{b}} \pm 0,01$ & $0.68^{\mathrm{b}} \pm 0,01$ & $0.63^{c} \pm 0,01$ \\
\hline
\end{tabular}

${ }^{2}$ Averages followed by different letters in the same line are significantly different $(\mathrm{p}<0.05)$ according to Tukey's test. SFA, total saturated fatty acid; MUFA, total monounsaturated fatty acid; PUFA, total polyunsaturated fatty acid; $\mathrm{n}-6$, total $\mathrm{n}-6$ fatty acid; $\mathrm{n}-3$, total $\mathrm{n}-3$ fatty acid; SE, standard error; $\mathrm{nd}$, not detected (detection limit $=0.015 \mathrm{mg} \mathrm{g}^{-1}$ ). ${ }^{\text {bSFA }}=$ sum of saturated fatty acids. ${ }^{\mathrm{C}}$ MUFA $=$ sum of monounsaturated fatty acids. ${ }^{\mathrm{d}} \mathrm{PUFA}=$ sum of polyunsaturated fatty acids. ${ }^{\mathrm{e}} \mathrm{n}-6=$ sum of omega 6 fatty acids. ${ }^{\mathrm{f}} \mathrm{n}-3=$ sum of omega 3 fatty acids. ${ }^{\mathrm{g}} \mathrm{d}=$ not detected.

For illustration reasons, Figure 1 show examples of the chromatograms that were obtained for the rations and treatments.

\section{Conclusion}

Although no significant difference was observed between moisture, ash, and crude protein data of all fish evaluated after 50 days (save for the ash content of fish fed diet II in relation to those that were fed diet I) through absolute quantification of fatty acids by gas chromatography, it can be said that fish rations enriched with flaxseed oil and CLA led to a nutritional improvement of the studied fish fillets. These facts are corroborated by the improvements in their omega-6/omega-3 ratios.

\section{Acknowledgements}

The authors thank the Aquaculture and Management Research Group at Unioeste, Toledo, Brazil; Itaipu Binational, Foz do Iguaçu, Brazil; and Conselho Nacional de Desenvolvimento Científico e Tecnológico (CNPq) for the financial support.

\section{References}

ANALYTICAL METHODS COMMITTEE. Recommendations for the Definition, Estimation and Use of the Detection Limit. Analyst, v. 112, p. 199-204, 1987. http://dx.doi.org/10.1039/AN9871200199

BANDARRA, N. M. et al. Effect of dietary conjugated linoleic acid on muscle, liver and visceral lipid deposition in rainbow trout juveniles (Oncorhynchus mykiss). Aquaculture, v. 254, p. 496-505, 2006. http://dx.doi.org/10.1016/j.aquaculture.2005.10.034 
BENDIKSEN, E. Å.; ARNESEN, A. M.; JOBLING, M. Effects of dietary fatty acid profile and fat content on smolting and seawater performance in Atlantic salmon (Salmo salar L.). Aquaculture, v. 225 , p. $149-163,2003$. http://dx.doi.org/10.1016/S00448486(03)00286-2

BLANCHARD, G.; MAKOMBU, J. G.; KESTEMONT, P. Influence of different dietary 18:3n-3/18:2n-6 ratio on growth performance, fatty acid composition and hepatic ultrastructure in Eurasian perch, Perca fluviatilis. Aquaculture, v. 284, p. 144-150, 2008. http://dx.doi. org/10.1016/j.aquaculture.2008.07.011

BLIGH, E. G.; DYER, W. J. A rapid method of total lipid extraction and purification. Canadian Journal of Biochemistry and Physiology, v. 37, p. 911-917, 1959. PMid:13671378. http://dx.doi.org/10.1139/ o59-099

CUNNIFF, P. A. Official Methods of Analysis of AOAC International. 16th ed. Arlington: Association of Official Analytical Chemists, 1998.

FIGUEIREDO-SILVA, A. C. et al. Effects of dietary conjugated linoleic acid on growth, nutrient utilization, body composition, and hepatic lipogenesis in rainbow trout juveniles (Oncorhynchus mykiss). Aquaculture, v. 248, p. 163-172, 2005. http://dx.doi.org/10.1016/j. aquaculture.2005.04.022

GHANAWI, J. et al. Effects of dietary lipid levels on growth performance of marbled spinefoot rabbitfish Siganus rivulatus. Aquaculture, v. 310, p. 395-400, 2011. http://dx.doi.org/10.1016/j. aquaculture.2010.11.012

GODOY, M. P. D. E. Peixes do Estado de Santa Catarina, first ed. Florianópolis: Editora da UFSC, 1987.

GULER, G. O. et al. Determination of the seasonal changes on total fatty acid composition and $\omega 3 / \omega 6$ ratios of carp (Cyprinus carpio L.) muscle lipids in Beysehir Lake (Turkey). Food Chemistry, v. 108, p. 689-694, 2008. http://dx.doi.org/10.1016/j.foodchem.2007.10.080

HARTMAN, L.; LAGO, R. C. A. Rapid preparation of fatty acid methyl esters from lipids. Laboratory Practice, v. 22, p. 475-476, 1973. PMid:4727126.

HER MAJESTY'S STATIONERY OFFICE - HMSO. Nutritional Aspects of Cardiovascular Disease. London: HMSO, 1994. Report on Health and Social Subjects, n. 46.

HUYNH, M. D.; KITTS, D. D. Evaluating nutritional quality of pacific fish species from fatty acid signatures. Food Chemistry, v. 114, p. 912-918, 2009. http://dx.doi.org/10.1016/j.foodchem.2008.10.038

INHAMUNS, A. J.; FRANCO, M. R. B.; BATISTA, W. S. Seasonal variations in total fatty acid composition of muscles and eye sockets of tucunaré (Cichla sp.) from the Brazilian Amazon area. Food Chemistry, v. 117, p. 272-275, 2009. http://dx.doi.org/10.1016/j. foodchem.2009.03.113

JI, H.; LI, J.; LIU, P. Regulation of growth performance and lipid metabolism by dietary n-3 highly unsaturated fatty acids in juvenile grass carp, Ctenopharyngodon idellus. Comparative Biochemistry and Physiology Part B: Biochemistry and Molecular Biology, v. 159, p. 49-56, 2011. PMid:21296179. http://dx.doi.org/10.1016/j. cbpb.2011.01.009

JOSEPH, J. D.; ACKMAN, R. G. Capillary column gas chromatography method for analysis of encapsulated fish oil and fish oil ethyl esters: Collaborative study. Journal of AOAC International, v. 75, p. 488506, 1992.

JUSTI, K. C. et al. The influence of feed supply time on the fatty acid profile of Nile tilapia (Oreochromis niloticus) fed on a diet enriched with n-3 fatty acids. Food Chemistry, v. 80, p. 489-493, 2003. http:// dx.doi.org/10.1016/S0308-8146(02)00317-5
KENNEDY, S. R. et al. Influence of dietary conjugated linoleic acid (CLA) on lipid and fatty acid composition in liver and flesh of Atlantic salmon (Salmo salar). Comparative Biochemistry and Physiology Part B: Biochemistry and Molecular Biology, v. 141, p. 168-178, 2005. PMid:15939320. http://dx.doi.org/10.1016/j. cbpc.2005.02.010

KENNEDY, S. R. et al. Influence of conjugated linoleic acid (CLA) or tetradecylthioacetic acid (TTA) on growth, lipid composition, fatty acid metabolism and lipid gene expression of rainbow trout (Oncorhynchus mykiss L.). Aquaculture, v. 272, p. 489-501, 2007. http://dx.doi.org/10.1016/j.aquaculture.2007.06.033

LEAVER, M. J. et al. Effect of dietary conjugated linoleic acid (CLA) on lipid composition, metabolism and gene expression in Atlantic salmon (Salmo salar) tissues. Comparative Biochemistry and Physiology Part B: Biochemistry and Molecular Biology, v. 145, p. 258-267, 2006.

LOLIS, A. A.; ANDRIA, I. F. Alimentação de Pimelodus maculatus Lacépède 1803 (Siluriformes, Pimelodidae), na planície de inundação do Alto Rio Paraná, Brasil. Boletim do Instituto de Pesca, v. 23, p. 187-202, 1996.

MANNING, B. B. et al. Enrichment of channel catfish (Ictalurus punctatus) fillets with conjugated linoleic acid and omega-3 fatty acids by dietary manipulation. Aquaculture, v. 261, p. 337-342, 2006. http://dx.doi.org/10.1016/j.aquaculture.2006.07.029

MARTINO, R. C. et al. Performance and fatty acid composition of surubim (Pseudoplatystoma coruscans) fed diets with animal and plant lipids. Aquaculture, v. 209, p. 233-246, 2002. http://dx.doi. org/10.1016/S0044-8486(01)00847-X

MEMON, N. N. et al. Changes in fatty acid composition in muscle of three farmed carp fish species (Labeo rohita, Cirrhinus mrigala, Catla catla) raised under the same conditions. Food Chemistry, v. 126, p. 405-410, 2011. http://dx.doi.org/10.1016/j.foodchem.2010.10.107

NATIONAL RESEARCH COUNCIL - NRC. Nutrient requirements of warmwater fishes and shellfishes, first ed. Washington: National Academy Press, 1993.

NAVARRO, R. D. et al. Quality of polyunsaturated fatty acids in Nile tilapias (Oreochromis niloticus) fed with vitamin E supplementation. Food Chemistry, v. 134, p. 215-218, 2012. http://dx.doi. org/10.1016/j.foodchem.2012.02.097

NG, W. K.; WANG, Y. Inclusion of crude palm oil in the broodstock diets of female Nile tilapia, Oreochromis niloticus, resulted in enhanced reproductive performance compared to broodfish fed diets with added fish oil or linseed oil. Aquaculture, v. 314, p. 122131, 2011. http://dx.doi.org/10.1016/j.aquaculture.2011.01.034

RAHMAN, S. A. et al. Fatty acid composition of some Malaysian freshwater fish. Food Chemistry, v. 54, p. 45-49, 1995. http://dx.doi. org/10.1016/0308-8146(95)92660-C

RAMOS, A. et al. Time course deposition of conjugated linoleic acid in market size rainbow trout (Oncorhynchus mykiss) muscle. Aquaculture, v. 274, p. 366-374, 2008. http://dx.doi.org/10.1016/j. aquaculture.2007.11.040

RODRIGUÉZ, C.; PÉREZ, J. A.; HENDERSON, R. J. The esterification and modification of n-3 and n-6 polyunsaturated fatty acids by hepatocytes and liver microsomes of turbot (Scophthalmus maximus). Comparative Biochemistry and Physiology Part B: Biochemistry and Molecular Biology, v. 132, p. 559-570, 2002. http:// dx.doi.org/10.1016/S1096-4959(02)00072-6

SAITO, H.; OKABE, M. Characteristics of lipid composition differences between cultured and wild ayu (Plecoglossus altivelis). Food Chemistry, v. 131, p. 1104-1115, 2012. http://dx.doi.org/10.1016/j. foodchem.2011.09.069 
SARGENT, J. et al. Recent developments in the essential fatty acid nutrition of fish. Aquaculture, v. 177, p. 191-199, 1999. http:// dx.doi.org/10.1016/S0044-8486(99)00083-6

SCHIEPERS, O. J. G. et al. Fish consumption, not fatty acid status, is related to quality of life in a healthy population. Prostaglandins Leukotrienes and Essential, v. 83, p. 31-35, 2010. PMid:20207122. http://dx.doi.org/10.1016/j.plefa.2010.02.030

SIMOPOULOS, A. P. Evolutionary aspects of diet: the omega-6/ omega-3 ratio and the brain. Molecular Neurobiology, v. 44, p. 203-215, 2011. PMid:21279554. http://dx.doi.org/10.1007/ s12035-010-8162-0

SMITH, D. M. et al. Essential fatty acids in the diet of silver perch (Bidyanus bidyanus): Effect of linolenic and linoleic acid on growth and survival. Aquaculture, v. 236, p. 377-390, 2004. http://dx.doi. org/10.1016/j.aquaculture.2003.10.021

TAN, X.-Y. et al. Effect of dietary conjugated linoleic acid (CLA) on growth performance, body composition and hepatic intermediary metabolism in juvenile yellow catfish Pelteobagrus fulvidraco. Aquaculture, v. 310, p. 186-191, 2010. http://dx.doi.org/10.1016/j. aquaculture.2010.10.011

TURCHINI, G. M.; FRANCIS, D. S.; DE SILVA, S. S. Fatty acid metabolism in the freshwater fish Murray cod (Maccullochella peelii peelii) deduced by the whole-body fatty acid balance method. Comparative Biochemistry and Physiology Part B: Biochemistry and Molecular Biology, v. 144, 110-118, 2006. PMid:16513379. http://dx.doi.org/10.1016/j.cbpb.2006.01.013

TURCHINI, G. M. et al. Effects of dietary lipid source on fillet chemical composition, flavour volatile compounds and sensory characteristics in the freshwater fish tench (Tinca tinca L.). Food Chemistry, v. 102, p. 1144-1155, 2007. http://dx.doi.org/10.1016/j. foodchem.2006.07.003

TWIBELL, R. G.; WILSON, R. P. Effects of dietary conjugated linoleic acids and total dietary lipid concentrations on growth responses of juvenile channel catfish, Ictalurus punctatus. Aquaculture, v. 221, p. 621-628, 2003. http://dx.doi.org/10.1016/S0044-8486(03)00118-2

VISENTAINER, J. V. et al. Influence of diets enriched with flaxseed oil on the $\alpha$-linolenic, eicosapentaenoic and docosahexaenoic fatty acid in Nile tilapia (Oreochromis niloticus). Food Chemistry, v. 90, p. 557-560, 2005. http://dx.doi.org/10.1016/j.foodchem.2004.05.016

$\mathrm{XU}$, J. et al. Analysis of nutrient composition and fatty acid profiles of Japanese sea bass Lateolabrax japonicus (Cuvier) reared in seawater and freshwater. Journal of Food Composition and Analysis, v. 23, p. 401-405, 2010. http://dx.doi.org/10.1016/j.jfca.2010.01.010

WU, F.-C.; CHEN, H.-Y. Effects of dietary linolenic acid to linoleic acid ratio on growth, tissue fatty acid profile and immune response of the juvenile grouper Epinephelus malabaricus. Aquaculture, v. 324-325, p. 111-117, 2012. http://dx.doi.org/10.1016/j. aquaculture.2011.10.030

ŻMIJEWSKI, T. et al. Slaughter yield, proximate and fatty acid composition and sensory properties of rapfen (Aspius aspius L) with tissue of bream (Abramis brama L.) and pike (Esox lucius L). Journal of Food Composition and Analysis, v. 19, p. 176-181, 2006. http://dx.doi.org/10.1016/j.jfca.2005.03.006

ZURAINI, A. et al. Fatty acid and amino acid composition of three local Malaysian Channa spp. fish. Food Chemistry, v. 97, p. 674-678, 2006. http://dx.doi.org/10.1016/j.foodchem.2005.04.031 